\title{
Knowledge, Attitude, Beliefs and Motivations of People in Western Part of Turkey Regarding Blood Donation
}

\section{Neval Agus ${ }^{1}$, Nisel Yilmaz ${ }^{2 *}$ and Haluk Agus $^{3}$}

${ }^{1}$ Department of Blood Bank, Tepecik Educational and Research Hospital, Izmir, Turkey

${ }^{2}$ Department of Microbiology Laboratory, Tepecik Educational and Research Hospital,Izmir, Turkey

${ }^{3}$ Department of Ortopaedia and Traumatology Clinic, Tepecik Educational and Research Hospital, Izmir, Turkey

"Corresponding author: Nisel Ozkalay Yilmaz, Department of Microbiology Laboratory, Tepecik Educational and Research Hospital, Microbiology Laboratory, İzmir, Turkey, Tel: +90-232-4696969; Fax: +90-232-4330756; E-mail: niseloz@yahoo.com

Received date: Feb 20, 2015, Accepted date: Mar 26, 2015, Publication date: Mar 30, 2015

Copyright: (c) 2015 Agus N, et al. This is an open-access article distributed under the terms of the Creative Commons Attribution License, which permits unrestricted use, distribution, and reproduction in any medium, provided the original author and source are credited.

\begin{abstract}
Introduction: The blood donor system in Turkey depends mainly on voluntary donors. We think that the attitude and beliefs of people can keep them away from voluntary donation. We aimed to evaluate the factors influencing blood donation in Turkish population in the present study.

Material and Methods: A self-administered questionnaire was developed for the assessment of various aspects of the attitudes, beliefs and positive/negative effects on blood donation. A random sampling technique was used to choose the participants from among donors and non-donors. The rate of consent to the study was $91 \%$ among donors. One thousand and thirteen subjects (488 donors, 525 non-donors) completed the questionnaire and answered the questions.
\end{abstract}

Results: Among donors, gender wise men donors were found significantly higher than women $(P<0.05)$. Repeat donors were significantly higher $(p<0.05)$ than the first time donors. Most of donors were donated to help someone else (65.2\%). Positive and negative effects were described $70.4 \%$ (347), $11.7 \%$ (57), respectively. Never had to opportunity to donate and health problems were found to be the common reasons for not donating blood in nondonor group.

Discussion: It is recommended that an intensive blood donation campaign should be maintained. This will allow people to be well informed, turning the positive attitude of saving life through blood donation to a regular practice.

Keywords: Blood donation; Knowledge; Beliefs; Turkey

\section{Introduction}

Despite all advances in medicine there is still not a substitute for human blood and blood donors play an important role in health systems as a main source of blood supply. On the other hand safety blood transfusion is major concern for human health that prevents the spread of infectious diseases. Therefore establishment of effective national blood systems are crucial for the safety and accessibility of human blood and blood products [1,2]. Many differences exit about donor recruitments in different countries. Besides significant alterations also exit in rural or urban areas within the same country. Cultural, social, educational and other factors may have negative or positive effects on blood donors [3]. The blood donor system in Turkey depends mainly on voluntary donors. We think that the attitude and beliefs of people can keep them away from voluntary donation. We aimed to evaluate the factors influencing blood donation in Turkish population in the present study.

\section{Materials and Methods}

We conducted a pilot study at the blood center of a training and research hospital in western part of Turkey, Izmir. A self-administered questionnaire was developed for the assessment of various aspects of the attitudes, beliefs and positive/negative effects on blood donation. A random sampling technique was used to choose the participants from among donors and non-donors. People who donated blood at our center were enrolled into the study as donors. The relatives of the donors who never donated blood and who accepted to participate to our study were included into the non-donor group. All statistical analyses were conducted using the SPSS (10) program. The MannWhitney $U$ test and chi-square $\left(\chi^{2}\right)$ was used to determine differences between the groups. The level of significance was set at $\mathrm{p}<0.05$.

\section{Results}

The rate of consent to the study was $91 \%$ among donors. One thousand and thirteen subjects (488 donors, 525 non-donors) completed the questionnaire and answered the questions. Overall, there were $874(86.3 \%)$ males and $139(13.7 \%)$ females. There was significantly more man in the donor group when compared with the non-donor group. Patient demographics of the donor group revealed that $(\mathrm{P}<0.05) ; 94.5 \%$ were married $(\mathrm{P}<0.05), 41.8 \%$ were between 26-35 years age group $(\mathrm{P}<0.05), 47.7 \%$ were secondary school graduated $(\mathrm{P}<0.05)$ and $60.4 \%$ of them were employed $(\mathrm{P}<0.05)$. Multiple donated donors were significantly higher than the single donated ones $(\mathrm{p}<0.05)$. In non-donor group $52.4 \%$ of the group were males, $61.1 \%$ were married, $40.6 \%$ were employed, $33.9 \%$ were $26-35$ 
Citation: $\quad$ Agus N, Yilmaz N, Agus H (2015) Knowledge, Attitude, Beliefs and Motivations of People in Western Part of Turkey Regarding Blood

Page 2 of 4

years age group, $40.2 \%$ were secondary school education. The demographic characteristics of participants is shown in Table 1.

\begin{tabular}{|c|c|c|c|}
\hline & $\begin{array}{l}\text { Donors } \quad(n: \\
488)\end{array}$ & Nondonors (n:525) & Total (n:1013) \\
\hline \multicolumn{4}{|l|}{ Age (years) } \\
\hline $18-25$ & $88(18.0)$ & $92(17.5)$ & $180(17.8)$ \\
\hline $26-35$ & $204(41.8)$ & $230(43.8)$ & $434(42.8)$ \\
\hline $36-45$ & $135(27.7)$ & $141(26.9)$ & $276(27.2)$ \\
\hline $46-55$ & $54(11.1)$ & $53(10.1)$ & 107 (10.6) \\
\hline$>56$ & $7(1.4)$ & $9(1.7)$ & $16(1.6)$ \\
\hline \multicolumn{4}{|l|}{ Gender } \\
\hline Male & $461(94.5)$ & $413(78.7)$ & $874(86.3)$ \\
\hline Female & $27(5.5)$ & $112(47.6)$ & 139 (13.7) \\
\hline \multicolumn{4}{|l|}{ Marital status } \\
\hline Married & $356(73)$ & $321(61.1)$ & $677(66.8)$ \\
\hline Unmarried & $132(27)$ & $204(38.9)$ & $336(33.2)$ \\
\hline \multicolumn{4}{|l|}{ Education } \\
\hline Elementary & $187(38.3)$ & $106(20.1)$ & $293(29)$ \\
\hline Intermediate & 85 (17.5) & $47(9)$ & $132(13)$ \\
\hline High school & $148(30.5)$ & $164(31.3)$ & $312(30.8)$ \\
\hline University & 68 (13.9) & $208(39.7)$ & $276(27.2)$ \\
\hline \multicolumn{4}{|l|}{ Occupation } \\
\hline None & $164(33.7)$ & $37(7.0)$ & $201(19.8)$ \\
\hline Employed & $283(58.2)$ & $345(65.8)$ & $628(62)$ \\
\hline Self Employed & $12(2.4)$ & $109(20.7)$ & $121(12)$ \\
\hline Student & $29(6)$ & $34(6.5)$ & $63(6.2)$ \\
\hline
\end{tabular}

Table 1: Demographic characteristics of participants (n,\%).

Multiple donated donors were significantly higher than the single donated ones $(\mathrm{p}<0.05)$. Most of donors were donated to help someone else (65.2\%).

Exclusively positive and negative effects were described $70.4 \%$ (347), $11.7 \%$ (57), respectively, while no effect was reported $17.2 \%$ (84). Donors' opinions about blood center were good (65\%) and they would think to donate again (78.9\%). Donors' opinions about donation is shown Table 2 .

\begin{tabular}{|l|l|}
\hline Frequency of donation & \\
\hline 1 & $132(27)$ \\
\hline $2-5$ & $197(40.4)$ \\
\hline $5<$ & $159(32.6)$ \\
\hline Opinion about blood center & \\
\hline
\end{tabular}

\begin{tabular}{|l|l|}
\hline Good & $317(65)$ \\
\hline Satisfactory & $106(21.7)$ \\
\hline Bad & $65(13.3)$ \\
\hline Disliked which aspect & \\
\hline None & $273(56)$ \\
\hline Behaviour of staff & $52(10.6)$ \\
\hline Donor room environment & $45(9.2)$ \\
\hline Long waiting period & $53(10.9)$ \\
\hline Unpleasant atmosphere & $48(9.8)$ \\
\hline Hard to filling the forms & $17(3.5)$ \\
\hline Why did you donate & \\
\hline To help someone else & $318(65.2)$ \\
\hline To be healty & $14(2.9)$ \\
\hline My friend/family need blood & $155(31.8)$ \\
\hline To learn blood group & $1(0.2)$ \\
\hline Effects of blood donation & $103(21.1)$ \\
\hline Nothing & $84(17.2)$ \\
\hline Positive effect & $209(42.8)$ \\
\hline Feeling of satisfaction & $57(11.7)$ \\
\hline Feeling healthy myself & $347(71.1)$ \\
\hline Subtotal & $50(10.2)$ \\
\hline Negative effect & \\
\hline Diminished physical capacity & \\
\hline Vertigo/dizziness & \\
\hline Subtotal & Would you donate again \\
\hline Yes & \\
\hline No & \\
\hline
\end{tabular}

Table 2: Blood donors' experience about donation (n:488,\%).

The most common reasons for male participants not donating blood were that they were busy having no time to donate $(37.7 \%)$, fear of a disease spread (12.1\%) and getting bored during donation (8.7\%). Whereas associated health problems $(28 \%)$, being busy having no time to donate $(26.8 \%)$, fear of a disease spread $(8 \%)$ were the common reasons for female participants cited for not donating blood. Nondonors' opinions on donation were shown in detail in Table 3.

\begin{tabular}{|l|l|l|}
\hline & Male (n:413) & Female (n:112) \\
\hline No time to donate & $156(37.7)$ & $30(26.8)$ \\
\hline $\begin{array}{l}\text { Donation process is long and } \\
\text { boring }\end{array}$ & $36(8.7)$ & $6(5.3)$ \\
\hline
\end{tabular}


Page 3 of 4

\begin{tabular}{|l|l|l|}
\hline Fear of diseases spread & $50(12.2)$ & $9(8)$ \\
\hline Health problems & $30(7.2)$ & $31(28)$ \\
\hline Donation is painfull & $21(5)$ & $8(7.1)$ \\
\hline Afraid of needle or sight of blood & $10(2.5)$ & $6(5.3)$ \\
\hline Donation is harmful to health & $22(5.3)$ & $8(7.1)$ \\
\hline
\end{tabular}

Table 3: Non-donors' attitude towards blood donation (n:525,\%).

\section{Discussion}

More detailed investigation of sex differences in donor motivation has found that women, more so than men, enjoy helping others, believe in a community responsibility to donate, and believe that donating is the right thing to do. In contrast, men appear to be more swayed by social pressure and are reluctant to disappoint someone who has asked them to donate $[4,5]$. The present study showed that there was a male prevalence among donors in Turkish population. Our demographic data revealed that females accounted for only $5.5 \%$ of our blood donors. This result is well correlated with most of the studies conducted in developing countries whereas different participation is reported from other countries [5,6]. This can be attributed to factors such as anemia, prevalent beliefs, customs, lifestyle and pregnancies in Turkish population [7]. There are some religious reasons to decrease in the number of donors, but only during Ramadan. Some people think that donation break their's fast. So the president of religious affairs declaretes that donation is not breaks one's fast and it is the duty of people to save the life of patient.

In our study, education of donors were found high school graduated (47.7\%). Studies in Tanzania [8], Nigeria [6] and Thailand [9] found that voluntary donations were correlated with secondary school education. Many previous studies have shown that, compared to general population, university students have a higher level of knowledge and a more positive attitude towards blood donation [5].

Dubey [5] was found that more of the voluntary donors than replacement donors had given blood repeatedly. The present study revealed that most of donors had given blood repeatedly $(73 \%)$ and their consideration about the blood center were generally good (65\%). The rate of blood donation for humanitarian reasons was $65.2 \%$ among our donors. Our data also indicated that family and social influences were also important.

The results presented in this study show that 404 of the 488 blood donors experienced an effect during blood donation. Despite majority of the donors $(70.4 \%)$ reported exclusively positive effects $(11.7 \%)$ reported negative effects. The most common positive and negative effects were the feeling of satisfaction (42.8\%) and diminished physical capacity $(10.2 \%)$, respectively. In some studies the frequency of negative reactions were found $25 \%$ [10], 18\% [5]. Vasovagal reactionlike complaints (vertigo/dizziness) were reported by seven subjects ( $1.4 \%$ of all donors) in our study, which is lower than the studies in the related literature (2-7\%) [10,11]. Interestingly, none of the blood donors reported complaints about local reactions such as bruise, hematoma or pain.

The majority of the donors (56\%) liked the aspects and reported an intend to donate $(78.9 \%)$ again. Long waiting period, unkind behaviour of the staff, the unpleasant atmosphere of the donation center were the main aspects disliked by the donors. Training of staff is mandatory in order to show more pleasant attitude towards the donors, listen them and their concerns, complaints and advices. Positive donation experience doe not only increases donors' intention to return but also their probability of donating again. In this study, being busy, having no time to donate and health problems were found to be the main excuses for not donating blood in non-donor group. Fear, risk of health and physical harm from blood donation was featured frequently in many studies [12-14].

Our results demonstrated that every effort should be made to modify non-donors' incorrect beliefs and attitudes about donation. Therefore in this way they could be motivated and start donating blood.

In conclusion, the results of our study highlighted the need for appropriate motivational organizations to improve the "favorable attitude" of non-donors towards blood donation. We were glad to reveal that most of the donors could be influenced to became regular/ repeat blood donors, as most agree that donation can be given more than once every year. Well-planned donor education programs should be established to promote voluntary blood donation aimed at better understanding fears and wrong concepts about dangers of donating blood.Well-planned donor education programme must include that;

There is no risk for health and blood transmission infections by donation, donation feels people better to help someone else, donation is not break one's fast during Ramadan .

There is a potential danger due to the alterations in societies leading to a decline in regular blood donations over the next decades in many developed countries. Therefore we should developed new strategies to overcome the intra-society changes in the attitude towards blood donation as an important altruistic behaviour.

\section{References}

1. http://www.who.int/worldblooddonorday/media/who\%20blood $\% 20$ safety.

2. Shenga N, Pal R, Sengupta S (2008) Behavior disparities towards blood donation in Sikkim, India. Asian J Transfus Sci 2: 56-60.

3. Abdel Gader AG, Osman AM, Al Gahtani FH, Farghali MN, Ramadan AH, et al. (2011) Attitude to blood donation in Saudi Arabia. Asian J Transfus Sci 5: 121-126.

4. Glynn SA, Kleinman SH, Schreiber GB, Zuck T, Combs SM, et al. (2002) Motivations to donate blood: demographic comparisons. Transfusion 42 : 216-225.

5. Dubey A, Sonker A, Chaurasia R, Chaudhary R1 (2014) Knowledge, attitude and beliefs of people in North India regarding blood donation. Blood Transfus 12 Suppl 1: s21-27.

6. Olaiya MA, Alakija W, Ajala A, Olatunji RO (2004) Knowledge, attitudes, beliefs and motivations towards blood donations among blood donors in Lagos, Nigeria. Transfus Med 14: 13-17.

7. Pala K, Dundar N (2008) Prevalence \& risk factors of anaemia among women of reproductive age in Bursa, Turkey. Indian J Med Res 128: 282-286.

8. Jacobs B, Berege ZA (1995) Attitudes and beliefs about blood donation among adults in Mwanza Region, Tanzania. East Afr Med J 72: 345-348.

9. Fishbein M, Ajzen I (1974) Attitudes toward objects as predictors of single and multiple criteria. Psychol Rev 81: 59-74.

10. Nilsson Sojka B, Sojka P (2003) The blood-donation experience: perceived physical, psychological and social impact of blood donation on the donor. Vox Sang 84: 120-128.

11. Schlumpf KS, Glynn SA, Schreiber GB, Wright DJ, Randolph Steele W, et al. (2008) Factors influencing donor return. Transfusion 48: 264-272. 
Citation: $\quad$ Agus N, Yilmaz N, Agus H (2015) Knowledge, Attitude, Beliefs and Motivations of People in Western Part of Turkey Regarding Blood Donation. J Blood Disorders Transf 6: 264. doi:10.4172/2155-9864.1000264

Page 4 of 4

12. Rados DL (1977) How donors and nondonors view people who do not give blood. Transfusion 17: 221-224.

13. Juárez-Ocaña S, Pizaña-Venegas JL, Farfán-Canto JM, Espinosa-Acevedo FJ, Fajardo-Gutiérrez A (2001) [Factors that influence non-donation of blood in relatives of patients at a pediatric hospital]. Gac Med Mex 137: 315-322.

14. Piliavin JA, Callero PL (1991) Giving blood: the development of an altruistic identity. Baltimore/London: Johns Hopkins University Press. 